\title{
The Effectiveness of Video Scribe Sparkol on EFL Students' Grammar Ability
}

\author{
Viola Putri Syafii \\ Universitas Islam Negeri Kiai Haji Achmad Siddiq Jember \\ Putrisyafii10@gmail.com \\ Ahmad Ridho Rojabi \\ Universitas Islam Negeri Kiai Haji Achmad Siddiq Jember \\ ahmadridhorojabi@gmail.com
}

\section{Article History}

Received: 13 August 2021

Reviewed: 22 August 2021

Accepted: 28 September 2021

Published: 30 September 2021

\section{Highlights}

The results of this study revealed that Video Scribe Sparkol impacts learners' grammar ability, and it can motivate and engage them in grammar activities.

\begin{abstract}
Grammar is one of the most important aspects as it integrates with four language skills, and it enhances the learners' fluency. However, some students still get difficulty in understanding the grammar patterns and difficulty in composing grammatical sentences. One of the methods that can be implemented in teaching grammar is Video Scribe Sparkol. This study intends to determine whether or not the employment of Video Scribe Sparkol influences students' grammatical skills. This quantitativeexperimental research involved the investigation of two classes; experimental and control. The experimental class was given treatment by using Video Scribe Sparkol, while the control class was taught conventionally (without using any media). The experimental class's SPSS data indicated that a pre-test average score was 68.15 , and the post-test average score was 83.23 . It indicated a highly significant improvement in the experimental class's score. Meanwhile, the average score of the control class's pre-test was 70.96, and their post-test average score was 78.09. As the significance sig. ( 2 tailed) of the Independent Sample t-test was $0.027<0.05$, which means that the null hypothesis $(\mathrm{H} 0)$ is rejected. Thus, there is a significant difference between the average score of the experimental and the control class. The results revealed that Video Scribe has a significant impact on learners' grammar ability, and it can motivate and engage them in grammar activities due to interesting images, animations, and audiovisuals on its features. Thus, further researchers need to investigate the students' motivation toward this method.
\end{abstract}

Keywords: experimental research, students' grammar ability, Video Scribe Sparkol

\section{Introduction}

English has been recognized as an international language. It is the most extensively used language for business correspondence that allows people to communicate with foreigners. More than 85 percent of research publications are written in English, even in IT, the majority of programs are written in English, and employees communicate with each other in the same language. Besides, the majority of books connected to higher education are also written in English. (Rao, 2019). Speaking, listening, reading, and writing are the four important skills in English. Writing and speaking are classified as productive skills while listening and reading are classified as receptive skills. Grammar is one of the most important aspects as it integrates with four language skills, 
and it enhances the learners' fluency. Thus, learners need to construct grammatical sentences in speaking as well as in writing. It requires a lot of practice and knowledge of grammar, vocabulary, sentence structure, and usage (Fithriani, 2018).

However, the majority of learners got difficulty in learning grammar, they did not understand the rule, even if they were aware of its meaning. For example, they recognized the meaning of "She drinks a cup of milk" and "She drunk a cup of milk," but they were perplexed as to why the sentences employed different verbs. The statement "She drinks a cup of milk" indicates that she consumes the milk in the present, but "She drunk a cup of milk" indicates that she consumes the milk in the past. It showed that individuals are unable to employ particular tenses in specific situations, as a result, the learners felt that learning English was a difficult task as it differed from the Indonesian language.

Based on the preliminary study, the majority of the students of $9^{\text {th }}$ grade at Mts Unggulan Al-Qodiri 1 Jember were unmotivated to learn English because the teacher's teaching technique was not engaging. The teacher demonstrates the rules explicitly when teaching grammar. Because many professors taught in traditional ways, such as writing the form on the blackboard and forcing the pupils to memorize the rule of tenses, they felt insecure and psychologically stressed.

Grammar is one of the most fundamental aspects of English. Grammar covers the structure of the English language as well as pronunciation, or the pronunciation of phrases that are appropriate for the present or past. These topics are covered in the tense content, making tenses a crucial skill to master. Students find it difficult to learn grammar. The majority of kids have difficulty in acquiring grammar. They are frequently perplexed by structure and tenses. As a result, many students receive poor grades in English because they are unable to understand grammar appropriately (Nurrahmatiah, 2010).

Learning grammar becomes important as it avoids misunderstanding in communication. In other words, the listeners can easily receive the messages from the speakers (Subasini \& Kokilavani, 2013). Grammar is meaningful when it is used to compose ideas and communicate with each other and is meaningless when it is used separately (Isyam \& Zainil, 2017). In brief, grammar instruction should encourage learners to have interactive and communicative performance in the classroom.

In the era of digital knowledge, Video Scribe Sparkol is deemed relevant and reliable as a learning medium in improving the teaching and learning process. It can be used to construct one-of-a-kind classes, and it has been employed by 63 academics throughout the world to facilitate interactive learning (Joyce et al., 2009). Furthermore, Video Scribe is entertaining as it provides interesting visuals to the learners (Air et al., 2015; Yani et al., 2020).

The benefit of using Video Scribe Sparkol is as a learning media. When animation and sound are combined, it is easier for the learners to learn than when animation and text are presented separately. When a person is studying, the greatest situation is when both words and visuals are offered at the same time, and when educational materials are presented simply, students can learn better (Sessu et al., 2018). Interesting learning videos are designed to impress the learners. By doing so, they are curious and motivated to learn more (Aksoy, 2012; Kumar, 2019; Maulina et al., 2019).

A previous study on the effectiveness of Video Scribe Sparkol was conducted by Sessu et al. (2018). They conducted an experimental study to examine the effectiveness of Video Scribe Sparkol on students' English achievement. The results revealed that 
Tell: Teaching of English Language and Literature Journal

Vol. 9, No.2, September 2021, Doi: http://dx.doi.org/10.30651/tell.v9i2.9443

this method was effective, there was a significant difference in students' scores before and after the treatment. Besides, the results revealed that there is a significant score difference between the experimental and the control group. Thus, this method can be implemented in English classes as it enhances students' motivation in studying English.

Another study on the effectiveness of Video Scribe Sparkol was conducted by Maulina et al. (2019). They conducted an experimental study to examine the effectiveness of Video Scribe Sparkol on students' speaking skills. The results revealed that this method was powerful as there was a positive impact on students' speaking skills. Besides, the results revealed that there is a significant score difference between the experimental group and the control group. In brief, this method provides fun and interesting learning videos and it can boost students' motivation in learning.

Many previous studies have explored the effectiveness of Video Scribe on students' grammar ability, they have exploited ordinary audio or audio initiator on Video Scribe. Yet, few studies exploited both an audio initiator in Video Scribe and the recordings of the teacher using English regarding simple present tense explanation. Once the teacher equips the recordings, not only do the students feel enthusiastic but also do they understand the materials provided. Therefore, this current research is needed to fill the previous research gap and answer the following research question: Is there any significant effect of Video Scribe Sparkol on Student Grammar Ability at 9th grade of MTs Unggulan AL Qodiri 1 Jember in Academic Year 2020/2021?.

\section{Method}

\section{Research Design}

The research design was quantitative, quasi-experimental research (Nonequivalent Control Group Design). Purposive sampling was used in this research as the selected participants could provide the detailed information needed. Besides, purposive sampling or non-probability sampling was chosen as it was easy to collect the data with a small population. Thus, the experiment and control groups were formed for the study. The first stage was to conduct preliminary testing for two-class groups. The experimental class received the treatment by implementing the Video Scribe Sparkol media, while the control group had no treatment, they received the conventional method. Both classes were given a post-test at the end of the session.

\section{Site and Participants}

The participants of this research were all of the 9th graders of MTs Unggulan ALQodiri 1 Jember which consists of 5 classes. The total number of students in the class was 130 and purposive sampling was utilized in this study. In this study, 23 students (10 boys and 13 girls) from 9th A grade were recruited to involve in the experimental class, while 26 students (12 boys and 14 girls) from 9th B grade were recruited to involve in the control class.

\section{The technique of Collecting Data and Research Instrument}

\section{Test}

The instrument of this study was multiple-choice grammar assessments. An objective test contains multiple-choice questions. The test had a total of 25 items, all of which were multiple-choice. The pre-test was administered before treatment, and the 
Tell: Teaching of English Language and Literature Journal

Vol. 9, No.2, September 2021, Doi: http://dx.doi.org/10.30651/tell.v9i2.9443

post-test was administered after the treatment. The pre-test was distributed before the treatment to obtain information about the student's prior knowledge, and the post-test was distributed after the treatment to obtain information about the effectiveness of utilizing Video Scribe.

\section{Instrument validity test}

The product-moment correlation formula was employed in this study's validity test utilizing the SPSS for Windows Series 22.0 Computer Program facility. This correlation technique was used to determine the validity of the item. If the correlation coefficient is 0.30 , it means that an item is regarded to be legitimate. If the number of valid items still does not reach the acceptable level, the criteria might be reduced from 0.30 to 0.25 or 0.20 . In this study, the researcher utilized 0.30 as the validity standard.

\section{Instrument reliability test}

The reliability test aimed to determine whether or not an instrument has the same result after being used repeatedly in different situations. The K-R 20 (KuderRichardson) formula was utilized in this study to determine the reliability of the measurement instrument employed to determine the effectiveness of Video Scribe Sparkol as a learning media using Microsoft Excel 2010 edition.

The K-R 20 (Kuder-Richardson) formula is appropriate for multiple-choice questions and questionnaires with a "yes" or "no" response. The researcher chose this technique as the instrument test was 25 items of multiple-choice. The decisionmaking process for the reliability coefficient is as follows: 1) 0.80-1.00: extremely high dependability 2) $0.60-0.80$ : a high level of dependability 3) $0.40-0.60$ : Reliability is moderate. 4) 0.20-0.40: a very low level of trustworthiness.

\section{TECHNIQUE OF DATA ANALYSIS}

\section{Normality Test}

The purpose of the normality test is to determine whether the distribution of data in a group of data or variables is regularly distributed or not. On SPSS 22, the researcher employed the Shapiro-Wilk normality test formula. If the sample size is less than 50 data points, the Shapiro-Wilk test is commonly utilized. As the sample size is only 49 people, the researcher opted to utilize this formula based on the hypothesis above (Razali \& Yap, 2011).

\section{Homogeneity Test}

The homogeneity test aimed to confirm that the data set being measured originates from the same population. To evaluate if the data in variables $\mathrm{X}$ and $\mathrm{Y}$ are homogeneous or not, a homogeneity test is used. The researcher utilized Levene's test on SPSS 22 to check for data homogeneity. The significant value (p) of two different data groups will be calculated as a result of this test. The data group originates from a population with the same variance, as indicated by the significance value $(p)>0.05$ (homogeneous), on the other hand, the significance value $(\mathrm{p})<0.05$ indicates that the data group comes from a population with different variances (heterogeneous). 
Tell: Teaching of English Language and Literature Journal

Vol. 9, No.2, September 2021, Doi: http://dx.doi.org/10.30651/tell.v9i2.9443

\section{Independent sample t-test}

On the interval/ratio data scale, an independent t-test is used to determine whether there is a significant difference in the mean between two independent groups. Subjects are divided into two categories, each of which is independent. As a result, an independent $\mathrm{t}-$ test is used to detect the difference in student mean scores between the control class and the experimental class. The SPSS 22 was used to perform the independent t-test. The results in the Sig column (2-tailed) were compared with Alpha research to make decisions for independent sample t-tests. If the value Sig. (2-tailed) < Research Alpha (0.05), then $\mathrm{HO}$ is rejected and $\mathrm{Ha}$ is accepted, or there is a significant difference between the mean scores of the control class and the experimental class. However, if the value Sig. (2-tailed) > Alpha Research (0.05), then $\mathrm{HO}$ is accepted and $\mathrm{Ha}$ is rejected or there is no significant difference between the mean scores of the control class and the experimental class.

\section{Findings and Discussion}

\section{Findings}

Dealing with the findings on the grammatical skills of 9th-grade pupils at MTs Unggulan Al-Qodiri 1 Jember, this research focused on two classes or groups. The experimental group was assigned to IX-A, whereas the control group was assigned to IXB. Purposive method sampling was used to choose them. The experimental group received Video Scribe as a learning tool, while the control group received no such tool (taught in conventional ways).

The researcher administered tests to both groups before and after the therapy to determine their grammar skills. Both the control and the experimental group received two types of tests. They were the pre-test, which was administered before the treatment, and the post-test, which was administered after the treatment. The pre-test was held in both classes on April 15, 2021, from 8:00 a.m. to 9:00 a.m. The researcher administered a multiple-choice simple present test to the students as a pre-test. Every student had 60 minutes to complete a 25 -items of choice test about a simple present. On April 17th, 2021, the researcher administered the treatment to the experimental group. The researcher provided the pupils a quick overview of the Video Scribe. The researcher provided several examples of sentences using the simple present in three sessions using the Video Scribe: the first was an explanation of the meaning and function of the simple present, the second was an explanation of the simple present formula, and the third was an explanation on how to make good sentences in simple present. The researcher played Video Scribe Sparkol in the first session, explained the meaning and function of the simple present, and then reviewed chapter 1 to chapter 3 to help students grasp the materials better. As one of the roles of learning media is to assist teachers in explaining content, the researcher was required to provide more explanation so that students were not confused in grasping the material provided.

Furthermore, the control group was taught in a traditional (non-media) way on April 18, 2021. The researcher explained the simple present materials in this class, similar to the experimental class, but it did not use any learning media. The researcher just wrote short materials on the blackboard and explained them to the students. Finally, 
the researcher gave the experimental and control groups a post-test on the 19th of 2020. The post-test was conducted by administering a multiple-choice basic simple present test to both groups, similar to the pre-test but with different material. This sort of test used an objective scoring rubric with 25 multiple-choice tests.

Table 1

Scoring Rubric

\begin{tabular}{cc}
\hline Total items & 25 \\
\hline Correct item & 4 \\
\hline Incorrect item & 0 \\
\hline Maximum score & 100
\end{tabular}

The researcher used point 4 for the correct answer as the total of the test was $25,100 / 25$ $=4$

If the students can answer 20 items so the scoring system will be $=20 \times 4=80$.

\section{Students' Grammar Score of The Pre-Test Experimental Class}

26-students of class IX-A as the experimental class were selected by the researcher. Only 9 students passed the Minimum Mastery Criterion (75), and 17 students had a score under the Minimum Mastery Criterion (75). The minimum score achieved by students was 40 , while the maximum score achieved by students was 88 .

\section{Control Class}

The control class was class IX-B consisting of 23 pupils in the class. Only ten students got scores above the Minimum Mastery Criterion (75), while thirteen students got scores under the Minimum Mastery Criterion (75). The minimum score achieved by students was 48, while the maximum score achieved by students was 92 .

\section{Students' Grammar Score of The Post-Test}

\section{Experimental Class}

The data revealed that only four students scored below the Minimum Mastery Minimum Criterion (75), with the remaining students passing the Minimum Mastery Criterion (75). The student's best achievement score was 96, and his lowest achievement score was 64. It can be noticed that the data given has raised scores from the pre-test results before and after Video Scribe was used as a learning medium.

\section{Control Class}

The data revealed that the mean score of the post-test was 78.60, based on the results of the post-test. Only six students had a score lower than the Minimum Mastery Minimum Criterion (75), while the remaining students passed the Minimum Mastery Minimum Criterion (75). The student's best achievement score was 92, and his lowest achievement score was 60 . 
Tell: Teaching of English Language and Literature Journal

Vol. 9, No.2, September 2021, Doi: http://dx.doi.org/10.30651/tell.v9i2.9443

\section{Data Analysis}

The data for this part was collected from two classes: the experimental and control. The purpose of the data analysis was to see how the two classes used in this study were compared. The experimental class was taught using Video Scribe as a learning tool, whereas the control group received traditional instruction. The data received from the pre-test and post-test were used to compare the value.

\section{Descriptive Analysis}

The researcher utilized SPSS version 22 to calculate the mean (M) and standard deviation (SD) of the students' grammar ability scores (SD). The Mean is the average of the student's scores, which can be calculated by summing all of the students' scores and dividing by the number of students. The standard deviation, on the other hand, is a measurement of how evenly the scores are distributed. The researcher divided the categorization into four parts in this section. They were the experimental group pretest, the experimental group post-test, the control group pre-test, and the control group post-test categories.

Table 2

The Descriptive Statistics

\begin{tabular}{cccccc}
\hline & $\mathrm{N}$ & Minimum & Maximum & Mean & Std. Deviation \\
\hline Pre-Test Experimental & 26 & 40 & 88 & 68.15 & 12.052 \\
\hline $\begin{array}{c}\text { Post-Test } \\
\text { Experimental }\end{array}$ & 26 & 64 & 96 & 83.23 & 8.468 \\
\hline Pre-Test Control & 23 & 48 & 92 & 70.96 & 11.519 \\
\hline Post-Test Control & 23 & 60 & 92 & 78.09 & 7.122 \\
\hline Valid N (listwise) & 23 & & & & \\
\hline
\end{tabular}

The information presented above is descriptive statistical analysis result information, which includes the minimum, maximum, mean, and standard deviation scores. We can find the mean or average score of the pre-test and post-test in the experimental and control classes by looking at the data above. The experimental class's post-test results differed significantly from the pre-test findings. This study indicates that Video Scribe Sparkol has a significant impact on students' grammar.

\section{Normality Test}

The normality test is the second step in the data analysis process. The purpose of the normality test in this study was to certify the absolute before statistical analysis. The researcher employed Shapiro-Wilk as a normality test technique in this phase. The significance value of $>0.05$ in the Shapiro-Wilk normality test indicates that the data is normally distributed. Shapiro-Wilk significance scores are all more than 0.05.

\section{Homogeneity Test}

Aside from validating the data's normal distribution, it is also important to see if the sample variance is homogeneous. The variance homogeneity test can be found in SPSS version 22. If the significance value is $<0.05$, it is said that the variants of two or more groups of the data population are not homogeneous. If the significance value is $>0.05$, it is said that the variants of two or more groups of the data population are homogeneous. Based on the result, the significance (sig.) was $0.355>0.05$. Thus, it can be concluded that the post-test data of the experimental class and control class are homogenous. It 
Tell: Teaching of English Language and Literature Journal

Vol. 9, No.2, September 2021, Doi: http://dx.doi.org/10.30651/tell.v9i2.9443

means that the data group comes from a population with the same variance (homogeneous).

\section{Independent Sample T-test}

An independent sample t-test aimed to determine whether the two sample groups had significant differences on the average or not. An independent sample t-test was conducted by testing the post-test data of the experimental class and the control class. The result is shown in table 3 below:

Table 3

The Output Data of Independent Sample T-test Levene's Test for Equality of Variances t-test for Equality of Means

\begin{tabular}{|c|c|c|c|c|c|c|c|c|c|}
\hline \multicolumn{5}{|c|}{ Levene’s Test for Equality of Variances } & \multicolumn{5}{|c|}{ t-test for Equality of Means } \\
\hline & $\mathrm{F}$ & Sig. & $\mathrm{t}$ & df & $\begin{array}{l}\text { Sig. (2- } \\
\text { tailed) }\end{array}$ & $\begin{array}{l}\text { Mean } \\
\text { Difference }\end{array}$ & $\begin{array}{l}\text { Std. Error } \\
\text { Difference }\end{array}$ & $\begin{array}{l}95 \% \mathrm{C} \\
\text { Interva } \\
\text { Differe }\end{array}$ & $\begin{array}{l}\text { ifidence } \\
\text { of the } \\
\text { ce }\end{array}$ \\
\hline & & & & & & & & Lower & Upper \\
\hline $\begin{array}{l}\text { Equal } \\
\text { variance } \\
\text { assumed }\end{array}$ & .874 & .355 & 2.284 & 47 & .027 & 5.14381 & 2.25179 & 61379 & 9.67384 \\
\hline $\begin{array}{l}\text { Equal } \\
\text { variance not } \\
\text { assumed }\end{array}$ & & & 2.309 & 46.894 & 0.25 & 5.14381 & 2.22779 & .66180 & 9.62582 \\
\hline
\end{tabular}

The comparison of the results in the Sig column (2-tailed) with Alpha research can be used to make decisions for independent sample t-tests.

In conclusion, if the value Sig. (2-tailed) of Independent Sample T-test is < Research Alpha (0.05), the alternative hypotheses (Ha) is accepted, and if the value Sig. (2-tailed) of Independent sample t-test is > Research Alpha (0.05), the null hypothesis (H0) is accepted. As the significance sig. (2 tailed) of Independent Sample t-test is 0.027 $<0$. 05, it means that the null hypothesis $(\mathrm{H} 0)$ is rejected. In conclusion, there is a significant difference between the mean scores of the control class and the experimental class.

\section{Discussion}

This current study aimed to investigate how the employment of Video Scribe Sparkol as a learning medium affects the students' grammatical ability. A grammar exam is one of the data collection methods utilized by the researcher. The grammar test was administered to 9th-grade students (both the experimental and control class). The researcher used a pre-test and post-test in the experimental class to compare students' grammar scores before and after treatment (Video Scribe Sparkol).

The average pre-test score in the experimental class before the treatment was 68.3, the least score was 40 and the maximum score was 88 . This indicates that the overall score was still low. Data analysis in the posttest displays 83.23 as a mean score, it is after the researcher taught the students by implementing Video Scribe Sparkol. Students received a minimum score of 64 and a maximum score of 96 on the post-test. The results reveal that using Video Scribe for grammar learning was very effective and it can be an alternative learning method in teaching grammar. Video Scribe not only motivates kids to learn but also improves their grammar skills. As reported by (Joyce et al., 2009)), Video Scribe can be utilized to build distinctive classes and it has been employed by 63 academics all around the world to facilitate interactive learning. 
Before employing Video Scribe as a learning medium to teach the simple present in class IX-A as an experimental class, the students of IX-A felt bored and drowsy during the te a ching and learning process, and they struggled to remember the existing simple present formula. They frequently had trouble distinguishing between different tense formulas. Many students struggled to answer questions during the pre-test period. However, after completing the treatment, several students were motivated to answer the grammatical questions on the post-test. Therefore, in the post-test, the students' scores experienced a significant increase as shown in the previous data. The powerful Video Scribe is that it provides animation videos so that it can facilitate and motivate the learners to learn effectively (Rosdiana et al., 2021; Wulandari, D, 2016)

As more visuals are displayed on-screen and explanations are shown more on the use of Video Scribe Sparkol in grammar class, students were motivated and they gained a better understanding of the content. This necessitated pupils became more engaged in class. It can be demonstrated in the experimental class, the students were excited during the teaching and learning process. Harmer (2007) confirms that the learners' motivation improved when language learning in the classroom is facilitated by using Video.

The researcher taught and described the simple present to class IX-B as a control group by utilizing traditional methods without Video Sparkol. The meaning of the simple present was explained, followed by functions, formulas, and examples of the simple present sentences. The researcher requested students to complete multiple-choice questions during the pre-test examination. Based on the results of the pre-test, many students could not understand the functions and applications of the basic present, particularly the application of the formula.

In the pre-test, the researcher taught and discussed the basic present simple tense, which was similar to the experimental class, but it did not involve any media. The researcher then administered 25 multiple-choice post-test questions. The students in the conventional course without learning media were less responsive than the students in the experimental class. Some students in the control class did not focus on understanding the material of simple present, while others did not understand some examples of simple present phrases during the learning process.

The experimental class had several advantages by receiving the material equipped with animation, videos, and images that can move differently. As a result, the students in the experimental class were motivated and interested to learn more deeply than the students in the control class who used a traditional blackboard or whiteboard. Some previous studies confirm that Video Scribe was effective in motivating the learners' participation in the language classroom as it provides the learners with fun animation videos, images, as well as audio-visual (Munawarah, 2019; Pahmi \& Syahfutra, 2019; Shalikhah \& Mardiana, 2019).

\section{Conclusion}

To optimize the teaching and learning process, especially in grammar classrooms, beneficial learning media need to be exploited. One of them is Video Scribe. Many studies have explored the effectiveness of Video Scribe on students' grammar ability. The results of this recent study reveal that Video Scribe has a significant impact on learners' grammar ability, and it can motivate and engage them in grammar activities due to interesting images, animations, and audiovisuals on its features. By implementing Video Scribe, The teachers need to facilitate the learners with enjoyable activities and a nice atmosphere of the classroom.

Future researchers are suggested to conduct the same topic with different research designs, research approaches, or other language skills. It also needs to be highlighted that Video Scribe can be an effective option for enhancing the learners' motivation to learn English better, not only in grammar class but also in other classes of English with different language skills, for instance in speaking class. 


\section{Syafii \& Rojabi}

Tell: Teaching of English Language and Literature Journal

Vol. 9, No.2, September 2021, Doi: http://dx.doi.org/10.30651/tell.v9i2.9443

\section{References}

Air, J., Oakland, E., \& Walters, C. (2015). The secrets behind the rise of Video scribing (2nd ed). Sparkol Ltd.

Aksoy, G. (2012). The effects of animation technique on the 7th grade science and technology course. Creative Education, 3(3), 304-308. https://doi.org/10.4236/ce.2012.33048

Fithriani, R. (2018). Communicative game-based learning in EFL grammar class: suggested activities and students' perception. JEELS (Journal of English Education and Linguistics Studies), 5(2), 171-188. https://doi.org/10.30762/jeels.v5i2.509

Harmer, J. (2007). The Practice of English Language teaching (4th ed). Longman.

Isyam, A., \& Zainil, Y. (2017). Meningkatkan kemampuan 'Grammar' mahasiswa jurusan bahasa Inggris FBS UNP secara lisan dan tulisan. Lingua Didaktika: Jurnal Bahasa Dan Pembelajaran Bahasa, 4(1), 1-17. https://doi.org/10.24036/ld.v4i1.7389

Joyce, B., Calhoun, E., \& Hopkins, D. (2009). Models of learning tools for teaching (third edit). Open University Press.

Kumar, M. A. S. (2019). Use of VideoScribe application in teaching: A comparative study. International Journal Clinicopathol Correllation, 3(1), 19-21. https://doi.org/https://www.ijcpc.org/text.asp?2019/3/1/19/261648

Maulina, U., Pahamzah, J., \& Hikmah, S. (2019). Attractive learning media to cope with students' speaking skills in the industry 4.0 using Sparkol Videoscribe. International Journal of Linguistics, Literature and Translation, 2(5), 132-140.

Munawarah, R. Al. (2019). Sparkol Videoscribe sebagai media pembelajaran. Jurnal Inspiratif Pendidikan, 8(2), 430-437. https://doi.org/10.24252/ip.v8i2.12412

Nurrahmatiah, S. (2010). Improving the students' grammar ability through EGRA (Exposure, Generalization, Reinforcement, Application) method of the second year students of SMP Moncoloe Makassar. Universitas Islam Negeri Alauddin Makassar.

Pahmi, \& Syahfutra, W. (2019). Development of learning media using VideoScribe for the subject of present continuous tense. Lectura Jurnal Pendidikan, 10(2), 184197. https://doi.org/10.31849/lectura.v10i2.3129

Rao, P. . (2019). The Importance of speaking skills in English classrooms. Alford Council of International English \& Literature Journal(ACIELJ), 2(2), 6-18.

Razali, N. ., \& Yap, B. W. (2011). Power comparisons of Shapiro-Wilk, KolmogorovSmirnov, Lilliefors and Anderson-Darling Tests. Journal of Statistical Modeling and Analytics, 2(1), 21-33.

Rosdiana, R., Al-Fahad, M. F., Mukhtar, R. H., \& Efendi, R. (2021). Implementation of learning media by using the Videoscribe application: Sparkol in developing competency of elementary school teachers. KaPIN Conference, 295-304.

Sessu, A., Sahlan, \& Laepe, A. (2018). The effectiveness of Video Scribe in teaching English at SMPN 1 Molawe Konawe Utara. Journal of Language Education and Educational Technology, 3(1), 1-11. https://doi.org/10.33772/jleet.v3i1.6666

Shalikhah, N. D., \& Mardiana, T. (2019). Edutainment with Video scribe in thematic learning. Journal of Physics: Conference Series, 1-8. https://doi.org/10.1088/1742-6596/1517/1/012058

Subasini, M., \& Kokilavani, B. (2013). Significance of grammar in technical english. International Journal of English Literature and Culture, 1(3), 56-58. 


\section{Syafii \& Rojabi}

Tell: Teaching of English Language and Literature Journal

Vol. 9, No.2, September 2021, Doi: http://dx.doi.org/10.30651/tell.v9i2.9443

https://doi.org/10.14662/IJELC2013.022

Wulandari, D, A. (2016). Pengembangan media pembelajaran Sparkol Video Scribe dalam meningkatkan minat belajar siswa pada mata elajaran IPA materi cahaya kelas VII di SMP Negeri 01 Kerjo tahun ajaran 2015/2016. Universitas Negeri Semarang.

Yani, M., Shahril, S., Putra, R. W. Y., \& Simatupang, A. T. (2020). Sparkol learning media: Is it effective to improve students' Mathematical understanding? Indonesian Journal of Science and Mathematics Education, 3(3), 329-335. https://doi.org/10.24042/ijsme.v3i3.5240

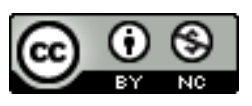

